\title{
Expression and functional implications of luteal endothelins in pregnant and non-pregnant dogs
}

\author{
Aykut Gram, Sophie Latter, Alois Boos, Bernd Hoffmann and Mariusz P Kowalewski \\ Vetsuisse Faculty, Institute of Veterinary Anatomy, University of Zurich, Winterthurerstrasse 260, CH-8057 Zurich, \\ Switzerland and ${ }^{1}$ Clinic for Obstetrics, Gynecology and Andrology of Large and Small Animals, Justus Liebig \\ University Giessen, Giessen, Germany
}

Correspondence should be addressed to M P Kowalewski; Email: kowalewskipl@yahoo.de; kowalewski@vetanat.uzh.ch

\begin{abstract}
Luteal development is regulated by many locally produced mediators, e.g., prostaglandins and angiogenic factors. However, the role and function of vasoactive factors in the canine corpus luteum $(\mathrm{CL})$ remain largely unknown. Consequently, expression of the endothelin (ET) receptors-A and -B (ETA and ETB, revealing vasoconstriction and vasodilator properties respectively), the ET-converting enzyme (ECE1) and $E T 1,-2$ and -3 were investigated in CL from non-pregnant dogs (days 5, 15, 25, 35, 45 and 65 post-ovulation), and at selected stages of pregnancy (pre-implantation, post-implantation, mid-gestation), and during normal and antigestagen-induced prepartum luteolysis/ abortion. The interrelationship between PGE2 and the ET system was investigated in PGE2-treated canine primary lutein cells from early CL. ET1 did not change significantly over time; ET2, ECE1 and ETB were elevated in early CL and were downregulated towards the $\mathrm{mid} /$ late-luteal phase. The prepartum increase of ET2 was significant. ET3 increased gradually, and was highest in late CL and/or at prepartum luteolysis. ETA remained constant until the late $C L$ phase and increased only during prepartum luteolysis. ET1 was localized to the luteal cells, and ET2, ET3 and ETA to vascular endothelium. ECE1 and ETB were detected at both locations. Except for upregulated ET1 and lack of effect on ET2, antigestagen applied to mid-pregnant dogs evoked similar changes to those observed during normal luteolysis. PGE2 upregulated ETB in treated cells; ETA and ET1 remained unaffected, and ET2 decreased. A modulatory role of the ETs in canine CL, possibly in association with other factors (e.g., PGE2 and progesterone receptor), is strongly indicated.
\end{abstract}

Reproduction (2015) 150 405-415

\section{Introduction}

The corpus luteum $(\mathrm{CL})$ is a highly vascularized, transient endocrine tissue. Its development and maintenance depend on an adequate blood supply (reviewed in Fraser \& Wulff (2003)). Prior to ovulation, the basement membrane of growing ovarian follicles constitutes the borderline between the vascularized and non-vascularized follicular compartments (Suzuki et al. 1998, Grazul-Bilska et al. 2007, Martelli et al. 2009, Kowalewski et al. 2015). Its rupture during ovulation is followed by rapid spreading of blood vessels into the follicular antrum and establishment of a dense vascular network that in mature CL provides virtually every lutein cell with access to a capillary. Thus, angiogenesis is an important process needed for rapid luteal formation. It is tightly regulated by numerous locally produced mediators such as angiogenic factors (Reynolds et al. 2000, Fraser \& Wulff 2003, Zalman et al. 2012). Among these, endothelins (ETs) play an important role in regulating many ovarian functions including vascularization, steroidogenesis, ovulation and folliculogenesis, as well as luteal regression and/or luteolysis
(Apa et al. 1998, Girsh \& Dekel 2002, Ko et al. 2006, Cacioppo et al. 2014). Endothelial-derived ETs consist of three different isoforms, ET1, -2 , and -3 , which convey their effects through ETA and ETB receptors (Yanagisawa et al. 1988, Nussdorfer et al. 1999). Although activation of ETA causes a pronounced vasoconstriction, ETB receptor occupation results in vasodilatation by induction of the nitric oxide pathway (Yanagisawa \& Masaki 1989). While ETA has a very high affinity for ET1 and ET2, ETB has a similar affinity to all the ET types (Nussdorfer et al. 1999). ET2 is the only ET that is upregulated in pre-ovulatory follicles at the time of ovulation and, as suggested for humans, rats and mice, its elevated levels might result from the hypoxic condition observed within growing follicles (Ko et al. 2006, Na et al. 2008, Bridges et al. 2010, Choi et al. 2011). The functional importance of ET2 and ETB for ovulation, $\mathrm{CL}$ formation and luteal P4 production was shown in mice (Palanisamy et al. 2006, Cacioppo et al. 2014). ETs also influence steroidogenesis through the activation of ETA (Iwai et al. 1991, Tedeschi et al. 1994, Kamada et al. 1995, Girsh et al. 1996). ET1 was shown to inhibit LH-, FSH- and hCG- stimulated P4 secretion by 
porcine, human and rat granulosa cells, as well as by cultured bovine luteal cells (Iwai et al. 1991, Flores et al. 1992, Tedeschi et al. 1994, Kamada et al. 1995, Girsh et al. 1996). Furthermore, as shown in cattle (Ohtani et al. 1998), ETs seem to be involved in PGF $2 \alpha$-induced luteolysis. Thus, utilizing a luteal microdialysis system and applying PGF2 $\alpha$ in cows, a steep rise in ET1 concentration was detected within the regressing $\mathrm{CL}$ as well as in the ovarian venous blood (Ohtani et al. 1998). Similarly, PGF $2 \alpha$ injections in sheep, cows and rabbits resulted in elevated luteal mRNA expression of ET1 (Milvae 2000, Wright et al. 2001, Boiti et al. 2007). Interestingly, in vivo blockage of the ETA receptor mitigated the ET1-mediated luteolytic action of PGF2 $\alpha$ in ewes and cows (Hinckley \& Milvae 2001, Watanabe et al. 2006).

In contrast to other mammalian species, none of the above information is available for the dog, a species in which the maintenance of pregnancy depends entirely upon the luteal secretion of P4 as its only major source, both in pregnant and non-pregnant cyclic animals.

As in other species, following ovulation and formation of the corpus hemorrhagicum, the canine CL is rapidly vascularized (see review in Kowalewski (2014)). During this time, PGs, especially PGE2, are among the most potent luteotropic factors regulating $\mathrm{CL}$ functions (Kowalewski et al. 2015). As concluded from the considerably decreased expression of vascular endothelial cell-bound endoglin (Hoffmann et al. 2004a,b), the vascularization rate slows down by the mid-luteal phase and does not change significantly later on, until the late luteal phase in non-pregnant bitches. From this, it has been concluded that the reduction of vascular network density does not seem to be the major factor regulating luteal regression in dogs (Hoffmann et al. $2004 a, b)$. Corroborating these results, expression of the vascular endothelial growth factor (VEGF) system also remained unaffected during prepartum luteolysis (Kowalewski 2014). The initially increased vasculogenic and angiogenic activities are evidenced by the expression of members of the VEGF system in steroidogenic and non-steroidogenic cells (Mariani et al. 2006, Papa Pde et al. 2013).

In order to fill the existing knowledge gap regarding the potential function of vasoactive factors in canine $\mathrm{CL}$ and thereby better understand the para/autocrine regulatory mechanisms governing its function, the present study investigated the expression and localization of ET1, -2 and -3 , and of ETA and ETB, as well as of the ET-converting enzyme (ECE1; responsible for activating ETs) in CL from non-pregnant and pregnant dogs at selected times during the luteal lifespan. Additionally, in view of PGE2 being one of the most important luteotropic factors in the dog, the effects of PGE2 on the ET system were investigated in canine primary lutein cells isolated from early CL.

\section{Materials and methods}

\section{Tissue collection and preservation}

Canine luteal samples were collected from experimental animals by routine ovariohysterectomy (OHE) during the nonpregnant luteal phase and pregnancy. The time of ovulation was determined by regular measurements of $\mathrm{P} 4$ concentrations in peripheral blood plasma at 2-3 day intervals and by vaginal cytology. The day when P4 levels reached at least $5 \mathrm{ng} / \mathrm{ml}$ was assigned as the day of ovulation (Concannon et al. 1989). Tissue samples were assigned to the following groups:

Non-pregnant dogs

Post-ovulation (p.o.) day $5(n=5)$, day $15(n=5)$, day $25(n=5)$, day $35(n=5)$, day $45(n=5)$ and day $65(n=5)$.

\section{Pregnant dogs}

Pre-implantation (days $8-12, n=5$ ), post-implantation (days $18-25, n=5$ ), mid-gestation (days 35-40, $n=5$ ) and prepartum luteolysis $(n=3)$. The day of mating was designated as day 0 and was 2-3 days after ovulation. In the pre-implantation group, pregnancies were determined by the presence of embryos in uterine flushings. Prepartum luteolysis was assessed by regular measurements of circulating $\mathrm{P} 4$ concentration at 6-h intervals beginning with gestational day 58; OHE was performed when $\mathrm{P} 4$ levels dropped below $3 \mathrm{ng} / \mathrm{ml}$ in two consecutive measurements. Additionally, abortions were induced in mid-pregnant dogs with an antigestagen, aglepristone (Alizine, Virbac, Bad Oldesloe, Germany; $10 \mathrm{mg} / \mathrm{Kg}$ bw, $2 \times / 24 \mathrm{~h}$ apart) and OHE was performed $24 \mathrm{~h}(n=5)$ and $72 \mathrm{~h}$ $(n=5)$ after the second treatment. All animal procedures were approved by the respective authorities for animal experiments at Justus Liebig University Giessen, Germany (permit no. II 25.3-19c20-15c GI 18/14 and VIG3-19c/2015c GI, 18,14) and by the Faculty of Veterinary Medicine, University of Ankara, Ankara, Turkey (permit no. Ankara 2006/06).

Tissue collection and preservation for immunohistochemistry (IHC) and non-radioactive in situ hybridization (ISH), protein extraction for western blot analysis and total RNA isolations for PCR reactions were performed as described previously (Kowalewski et al. 2010a, 2011, Gram et al. 2013). Thus, immediately after OHE, CL were trimmed of surrounding tissues and either placed in $10 \%$ neutral phosphate-buffered formalin for $24 \mathrm{~h}$ at $+4{ }^{\circ} \mathrm{C}$ for IHC and ISH, or immersed in RNAlater (Ambion Biotechnology $\mathrm{GmbH}$, Wiesbaden, Germany) for $24 \mathrm{~h}$ at $+4{ }^{\circ} \mathrm{C}$ and stored afterwards at $-80{ }^{\circ} \mathrm{C}$ until total RNA isolation or protein extraction.

\section{Primary luteal cell cultures}

Canine primary lutein cells were isolated from CL of clinically healthy bitches $(n=15)$, which underwent routine OHE early in diestrus, 7-14 days after the clinical signs of heat had ceased, and were used in our previous study determining the role of PGE2 in regulating canine luteal steroidogenic acute regulator (STAR) protein expression and steroidogenesis (Kowalewski et al. 2013). The mRNA obtained from that previous study was used in the present investigation to test the impact of PGE2 
treatment on the expression of genes encoding for members of the ET system. Briefly, cells were isolated using $0.15 \%$ Collagenase (Sigma-Aldrich Chemie $\mathrm{GmbH}$ ) and undissociated tissue was removed with a $75 \mu \mathrm{m}$ cell strainer (BD Biosciences, Basel, Switzerland). Following washing steps with PBS, cells were suspended in culture medium (DMEM/ F12, pH 7.2-7.4, 10\% heat-inactivated FBS, $100 \mathrm{U} / \mathrm{ml}$ penicillin and $100 \mu \mathrm{g} / \mathrm{ml}$ streptomycin, 1\% ITS (InsulinTransferrin-Selenium); all from Chemie Brunschwig, AG, Basel, Switzerland), seeded into six-well plates and maintained in a humidified incubator at $37^{\circ} \mathrm{C}$ under $5 \% \mathrm{CO}_{2}$, until reaching $70-80 \%$ confluency. The steroidogenic identity of isolated primary luteal cells was confirmed by immunocytochemical $3 \beta \mathrm{HSD}$ staining and STAR immunofluorescence staining (Kowalewski et al. 2013). Only non-trypsinized, 'passage $0^{\prime}$ cells were used for all experiments. Before treatments, cells were rinsed with pre-warmed sterile PBS, which was then replaced by serum-free medium, and used for stimulations with either $0.5 \mathrm{mM} \mathrm{N6}$, 2-dibutyryladenosine-3,

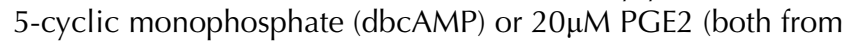
Sigma-Aldrich Chemie GmbH) for $6 \mathrm{~h}$. After treatment for $6 \mathrm{~h}$, upregulated expression of STAR mRNA and protein and significantly increased steroidogenic output were previously observed (Kowalewski et al. 2013).

\section{Immunohistochemistry}

IHC staining was based on our previously published protocol (Kowalewski et al. 2006a,b). Briefly, formalin-fixed paraffinembedded $\mathrm{CL}$ tissues were sectioned at $2 \mu \mathrm{m}$ thickness and transferred onto SuperFrost microscope slides (Menzel-Glaeser, Braunschweig, Germany), allowed to dry overnight at $37^{\circ} \mathrm{C}$, deparaffinized with xylene and rehydrated through a graded ethanol series. Epitopes were retrieved by microwave heating in $10 \mathrm{mM}$ citrate buffer $\mathrm{pH}$ 6.0. Slides were treated with $0.3 \%$ hydrogen peroxide in methanol to remove endogenous peroxidase activity. Then they were overlaid with $10 \%$ horse serum, which was used as a blocking serum to reduce nonspecific binding, and incubated overnight at $+4{ }^{\circ} \mathrm{C}$ with primary antibodies. The following primary antibodies were used: affinity purified goat polyclonal anti-ETA (sc-21194; dilution 1:50), affinity purified goat polyclonal anti-ETB (sc-21196; dilution 1:100), affinity purified goat polyclonal anti-ECE1 (sc-27558; dilution 1:300), all from Santa Cruz Biotechnology, Inc.; and mouse monoclonal anti-ET1 (E166; dilution 1:400) purchased from Sigma-Aldrich. As a negative control, sections were either incubated while omitting the primary antibody, or with non-immune IgGs of the same species instead of primary antibody (the so-called isotype control) applied at the same protein concentration. Following incubation of slides with biotin-labeled secondary antibodies at 1:100 dilution, signal intensity was amplified using the streptavidin-peroxidase Vectastain ABC kit (Vector Laboratories, Inc., Burlingame, CA, USA). The following secondary antibodies were used: biotinylated horse anti-goat IgG BA-9500, and horse anti-mouse IgG BA2000 (all from Vector Laboratories, Inc.). Peroxidase activity was visualized using the Liquid DAB + substrate kit (Dako Schweiz AG, Baar, Switzerland) and slides were counterstained with hematoxylin.

\section{Protein preparation and western blot analysis}

Only luteal samples from pregnant dogs were available for western blot analysis. Tissues were disrupted while maintaining the cold chain process throughout all procedures and homogenized in NET-2 lysis buffer $(50 \mathrm{mM}$ Tris- $\mathrm{HCl}, \mathrm{pH} 7.4$, $300 \mathrm{mM} \mathrm{NaCl}, 0.05 \% \mathrm{NP}-40$ ) containing $10 \mu \mathrm{l} / \mathrm{ml}$ protease inhibitor cocktail (Sigma-Aldrich). Following protein extraction, samples were centrifuged (10 $000 \mathrm{~g}$ for $10 \mathrm{~min}$, at $\left.4{ }^{\circ} \mathrm{C}\right)$, dissolved in sample buffer (25 mM Tris-Cl, pH 6.8, 1\% SDS, 5\% $\beta$-mercaptoethanol, $10 \%$ glycerol, $0.01 \%$ bromphenol blue) and SDS-PAGE was performed using $20 \mu \mathrm{g}$ of tissue homogenate per lane on $10 \%$ SDS-polyacrylamide gel as described previously (Kowalewski et al. 2010b, 2011, Sprekeler et al. 2012, Gram et al. 2013). Afterwards, proteins were blotted onto polyvinylidene difluoride (PVDF) membranes (Bio-Rad Laboratories $\mathrm{GmbH}$ ) and incubated overnight at $+4{ }^{\circ} \mathrm{C}$ with primary antibody diluted in PBS containing 2.5\% skimmed milk. Due to the limited availability of canine-specific or cross-reacting antibodies suitable for western blot analysis, experiments were restricted to detecting the ETB receptor. Goat polyclonal affinity-purified anti-human ETB primary antibody (same as for IHC; Santa Cruz Biotechnology) was used at 1:500 dilution. The specificity of the primary antibody was verified by blocking the anti-ETB antibody with the epitope-specific blocking peptide (sc-21196; Santa Cruz Biotechnology). Following incubation of membranes with HRP-conjugated secondary donkey anti-goat IgG sc-2056 antibody (Santa Cruz Biotechnology Inc.; dilution 1:15 000), the Immun-Star WesternC Chemiluminescent kit substrate (Bio-Rad) was applied according to the manufacturer's protocols and signals were detected using the ChemiDoc XRS + System and Image Lab (Bio-Rad). For internal loading control PVDF membranes were reblotted with monoclonal mouse anti$\beta$-ACTIN antibody (sc-69879; Santa Cruz Biotechnology, dilution 1:1000); secondary HRP goat anti-mouse IgG (W402B) from Promega was used at a dilution of 1:15 000. Image Software was applied for assessing the density of bands. Parametric one-way ANOVA followed by the Tukey-Kramer multiple comparison test was used to determine the effect of time on luteal ETB protein expression. The GraphPad 3.06 program (GraphPad Statistical Software, San Diego, CA, USA) was applied. Numerical data are presented as the mean \pm s.D. Representative western blots are shown.

\section{Total RNA isolation and real-time (TaqMan) PCR}

Total mRNA was obtained from CL of pregnant and nonpregnant dogs using TRIzol reagent following the manufacturer's directions (Invitrogen). Concentrations of isolated RNA were measured using a NanoDrop 2000C spectrophotometer (Thermo Fisher Scientific AG, Reinach, Switzerland). DNAse treatment and RT were performed following our previously published protocol (Kowalewski et al. 2006b, 2011). Then, expression of mRNA in luteal samples was determined by semi-quantitative real-time (TaqMan) PCR using an automated fluorometer (ABI PRISM 7500 Sequence Detection System, Applied Biosystems). The list of primers and TaqMan probes obtained from Microsynth (Balgach, Switzerland) together with amplicon sizes are presented in Table 1. 
Table 1 List of primers and TaqMan probes used for semi-quantitative RT-PCR.

\begin{tabular}{|c|c|c|c|}
\hline Primer & Acession number & Primer sequences & Product length (bp) \\
\hline GAPDH & AB028142 & $\begin{array}{l}\text { Forward: 5'-GCT GCC AAA TAT GAC GAC ATC A-3' } \\
\text { Reverse: 5'-GTA GCC CAG GAT GCC TTT GAG-3' } \\
\text { TagMan probe: 5'-TCC CTC CGA TGC CTG CTT CAC TAC CTT-3' }\end{array}$ & 75 \\
\hline 18SrRNA & FJ797658 & $\begin{array}{l}\text { Forward: 5'-GTC GCT CGC TCC TCT CCT ACT-3' } \\
\text { Reverse: } 5^{\prime} \text {-GGC TGA CCG GGT TGG TTT-3' } \\
\text { TaqMan probe: } 5^{\prime} \text {-ACA TGC CGA CGG GCG CTG AC-3' }\end{array}$ & 125 \\
\hline ETA & NM_001031632.1 & $\begin{array}{l}\text { Forward:5'-GGC CCCAAC GCA CTG ATA-3' } \\
\text { Reverse: } 5^{\prime} \text {-CCC GCC AGA AGC TTA AAC AC-3' } \\
\text { TaqMan probe:5'-CCA GCC TTG CCC TTG GAG ACC TTA TC-3' }\end{array}$ & 92 \\
\hline ETB & NM_001010943.2 & $\begin{array}{l}\text { Forward: 5'-CAT CAT CGG GAA CTC CAC ACT-3' } \\
\text { Reverse: 5'-CAG AGC CAG GCT GGC TAT CA-3' } \\
\text { TaqMan probe:5'-CAA GAA CAA GTG CAT GCG AAA CGG C-3' }\end{array}$ & 91 \\
\hline
\end{tabular}

The following commercially available TaqMan Gene Expression Assays from Applied Biosystems were used: ET1 (prod. no. Cf02622421_m1), ET2 (prod. no. Cf02622240_m1), ET3 (prod. no. Cf02622419- g1), ECE1 (prod. no. Cf02627515_m1) and CYCLOPHILIN A (prod. no. Cf03986523-gH). In order to exclude genomic DNA contamination, the so-called 'RT-minus controls' were run (i.e., samples where the RT reaction was omitted). Additional controls consisted of using autoclaved water instead of cDNA. The reaction mixture for all samples was prepared as follows: $200 \mathrm{nM}$ TaqMan Probe, $300 \mathrm{nM}$ of each primer, $12.5 \mu \mathrm{l}$ Fast Start Universal Probe Master (ROX) (Roche Diagnostics) and $5 \mu \mathrm{l}$ cDNA corresponding to $100 \mathrm{ng}$ total RNA per sample. All samples were run in duplicates. The thermal cycler steps were set as follows: denaturation at $95{ }^{\circ} \mathrm{C}$ for $10 \mathrm{~min}, 40$ cycles at $95^{\circ} \mathrm{C}$ for $15 \mathrm{~s}$ and 1 cycle at $60{ }^{\circ} \mathrm{C}$ for $60 \mathrm{~s}$. Efficiency of each target gene was calculated using the CT slope method and the relative gene expression was calculated using a comparative CT method ( $\Delta \Delta C T$ method) according to the manufacturer's protocols for the ABI PRISM 7500 Sequence Detection System (Applied Biosystems) and as described previously (Kowalewski et al. 2006b, 2011), and they were normalized using GAPDH, 18SrRNA and cyclophilin. Selected amplicons of each gene were sent for commercial sequencing (Microsynth).

The effects of the observational group on the expression of target genes in luteal samples were tested by one-way ANOVA followed by the Tukey-Kramer multiple comparison test. For samples obtained from induced abortions, Dunnett's multiple comparison test was performed; the results are presented as $n$-fold change in target expression compared to the expression at mid-gestation, which served as a non-treated control. In order to test for the effects of treatment with PGE2 on ET system expression in cell cultures, an unpaired two-tailed Student's $t$-test was performed; numerical data are presented either as $\mathrm{Xg} \pm \mathrm{DF}$ or mean \pm s.D. All statistical tests were performed with GraphPad 3.06 Software. Numerical data are presented as the mean \pm s.D. $P<0.05$ was considered statistically significant.

\section{In situ hybridization}

Due to the lack of canine-specific antibodies available for ET2 and ET3, non-radioactive ISH was used to localize their expression at the level of transcripts. Formalin-fixed, paraffin-embedded tissues were used and all procedures were performed following our previously published protocol (Kowalewski et al. 2006a). Primers used for generating cDNA templates for cRNA synthesis were as follows: ET2 forward: 5'-ACA TCA TCT GGG TGA ACA CT-3', ET2 reverse: 5'-CCT AGG AAA GCG GAT CTT-3' (amplicon length 262bp), ET3 forward: 5'-CTA TTG CCA CCT GGA CAT CA -3', ET3 reverse: 5'-GCT GGC TCT TCC TCT TTG TC-3' (amplicon length $258 \mathrm{bp}$ ). The PCR products were visualized using $2 \%$ ethidium bromide-stained agarose gel electrophoresis, isolated using the Qiaex II gel extraction system (Qiagen $\mathrm{GmbH}$ ) and subcloned into the pGEM-T vector (Promega). Upon linearization of plasmids with either Ncol or Notl restriction enzymes (New England Biolabs, Frankfurt, Germany), cRNA probes were synthesized by in vitro transcription with a DIG-RNA labeling kit (Roche Diagnostics). Plasmids were sent for commercial sequencing (Microsynth). Following incubation at $37^{\circ} \mathrm{C}$ overnight, the (DIG) digoxygenin-labeled CRNA probes were detected using alkaline phosphatase-conjugated sheep antiDIG Fab Fragments (Roche Diagnostics International) diluted 1:5000. The signals were visualized using 5-bromo-4-chloro3-indolyl phosphate and nitroblue tetrazolium (NBT/BCIP; Roche Diagnostics International) substrate.

\section{Results}

\section{Semi-quantitative assessment of gene expression.}

The expression of all target genes was detectable in CL of pregnant and non-pregnant animals at every luteal stage examined. Whereas the expression of ET1 mRNA did not change significantly over time, both in non-pregnant and pregnant animals $(P=0.91$ and $P=0.12$, respectively; Fig. $1 \mathrm{~A}$ and $\mathrm{B}$ ), the expression of ET2 and ET3 was significantly modulated in both situations showing timedependent effects, which differed at the end of the luteal lifespan $(P=0.01$ and $P<0.0001$ for ET2, and $P<0.0001$ and $P=0.0003$ for $E T 3$, in non-pregnant and pregnant bitches respectively). Thus, the expression of ET2 mRNA was upregulated during the early luteal phase in pregnant and non-pregnant animals and suppressed significantly by day 35 after ovulation in non-pregnant bitches compared with its highest expression at day 15 $(P<0.05)$. In pregnant dogs, ET2 mRNA decreased 

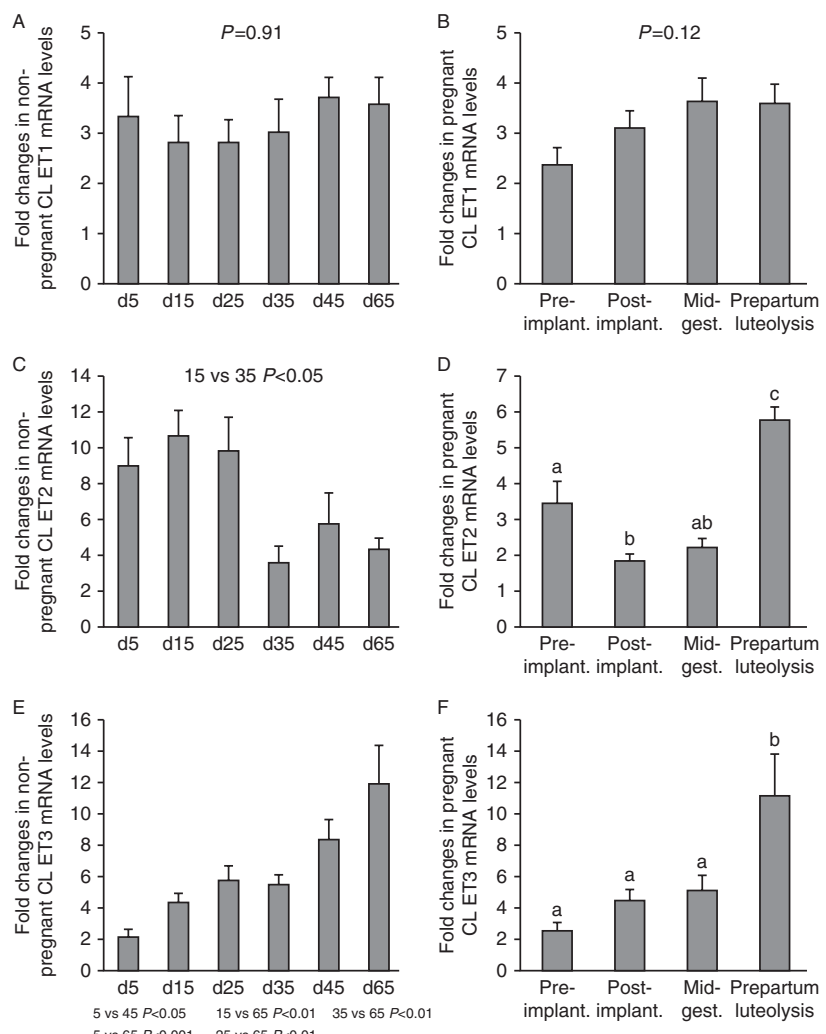

Figure 1 Time-dependent expression of canine endothelins (ET) -1, -2 and -3 as determined by real-time (TaqMan) PCR (mean \pm s.D.). (A, C and E) $\mathrm{CL}$ of non-pregnant dogs (days (d) 5-65 post-ovulation) and (B, D and F) $\mathrm{CL}$ of pregnant dogs. Bars with different letters differ at $P<0.05$.

significantly $(P<0.05)$ following implantation. While its expression remained low in the absence of pregnancy until the end of the observation period (day 65 p.o.) (Fig. 1C), a new and significant increase $(P<0.001)$ was noted in pregnant animals at the time of prepartum luteolysis (Fig. 1D). ET3 mRNA was lowest in early $\mathrm{CL}$, increased gradually with the development of the CL until the mid-luteal phase, and was significantly elevated during the late luteal stage in non-pregnant animals $(P<0.01$ for day 45 vs day 65 p.o.), or during prepartum luteolysis in pregnant ones $(P<0.05)$ (Fig. $1 \mathrm{E}$ and $\mathrm{F}$ ). As for ET receptors, ETA was expressed constantly in $\mathrm{CL}$ collected from non-pregnant females and did not change significantly throughout the luteal phase $(P=0.91)$ (Fig. 2A). This was in contrast to the situation observed in pregnant bitches, in which a time-dependent effect was observed $(P=0.04)$; prepartum luteolysis was associated with strongly upregulated ETA mRNA expression $(P<0.05)$ compared with the post-implantation stage of pregnancy (Fig. 2B). ETB mRNA was significantly altered over time $(P=0.0001)$ in both situations, i.e., during gestation and in non-pregnant cyclic dogs. It was strongly elevated in early $\mathrm{CL}$, followed by a significant decrease, which in nonpregnant animals was noted at day 25 after ovulation
$(P<0.001)$ compared with its highest expression at day 15 p.o. A further gradual decrease was observed towards day 65 p.o. $(P<0.01$ compared with day 15 p.o. $)$ (Fig. 2C). In pregnant bitches, ETB decreased significantly at mid-gestation $(P<0.01)$ compared with the pre-implantation stage of pregnancy, and remained low at prepartum luteolysis (Fig. 2D). Similarly, at the protein level ETB expression was modulated over time $(P<0.0001)$, being highest in early $\mathrm{CL}$, and exhibited significantly diminished levels $(P<0.001)$ at postimplantation and a further decrease $(P<0.001)$ at prepartum luteolysis (Fig. 3B). An expression pattern resembling that of ETB was observed for ECE1 (Fig. 2E and $\mathrm{F}$ ). Also here, the expression was time-dependent $(P=0.0005$ and $P=0.0008$ for pregnant and non pregnant females respectively), with the highest mRNA abundance in early $\mathrm{CL}$ (Fig. 2E and F). While its expression had already decreased strongly $(P<0.01)$ by day 15 p.o. in non-pregnant dogs, in pregnant animals the $E C E 1$ levels were significantly suppressed $(P<0.001)$ during prepartum luteolysis compared with the highest levels noted at the pre-partum stage of pregnancy (Fig. 2E and F).
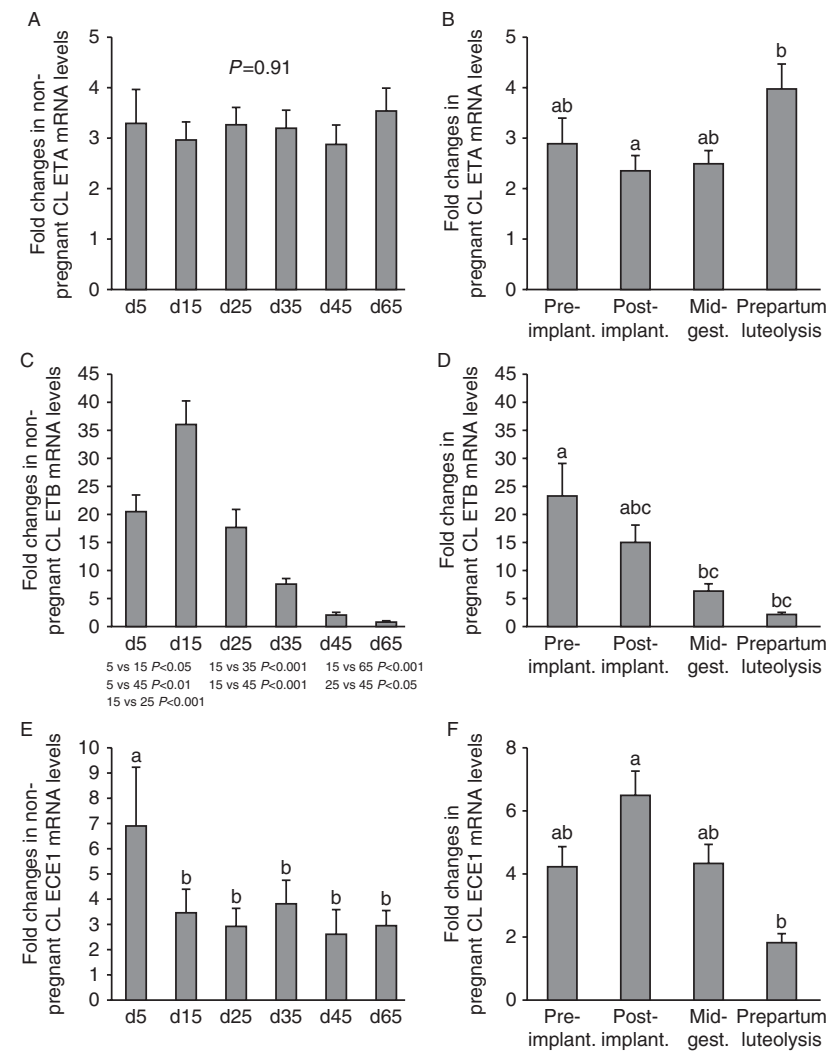

Figure 2 Expression of endothelin receptors - A and -B (ETA and ETB) and endothelin-converting enzyme 1 (ECE1) as determined by real-time (TaqMan) PCR (mean \pm s.D.) in the (A, C and E) CL from non-pregnant dogs (days (d) 5-65 post ovulation) and (B, D and F) CL collected at selected stages of pregnancy and during prepartum luteolysis. Bars with different letters differ either at $P<0.05$ in (B), or at $P<0.01$ in (D) and $(\mathrm{E})$, or $P<0.001$ in $(\mathrm{F})$. 
A $M$
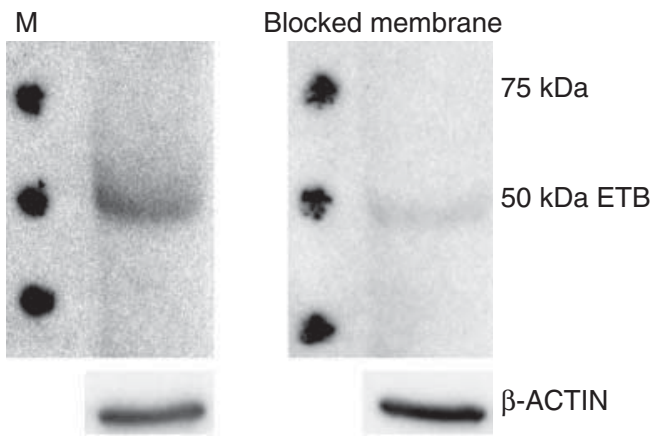

B $\mathrm{M}$

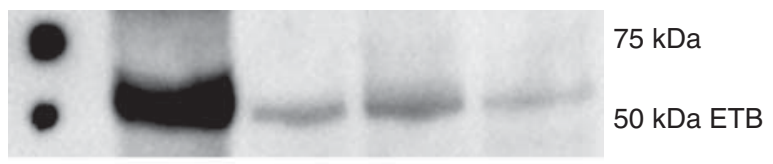

M
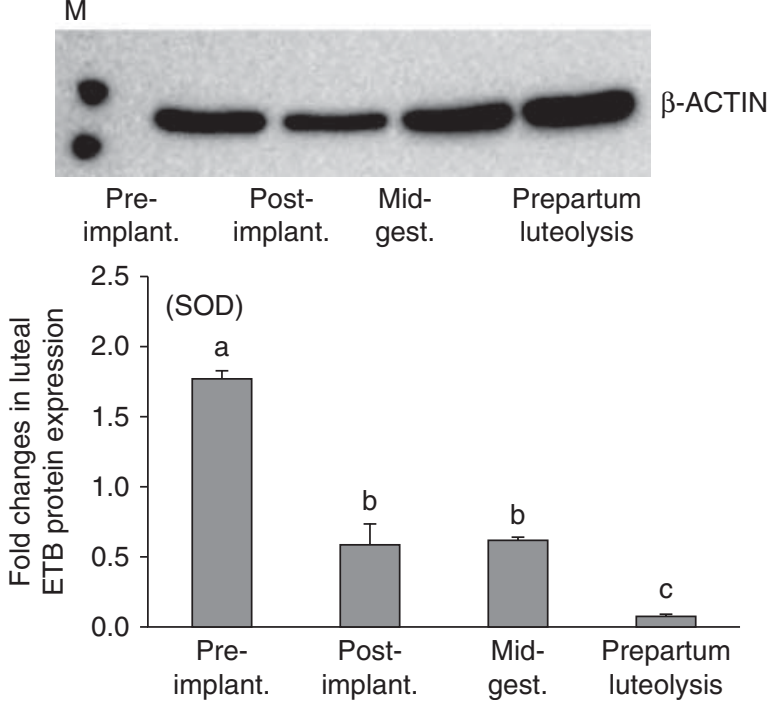

Figure 3 The expression of endothelin receptor B (ETB) ( $50 \mathrm{kDa})$ was determined by western blot analysis. Representative immunoblots are shown. (A) The epitope-blocking peptide was used to quench the ETB-specific signal in a luteal tissue homogenate derived from preimplantation CL. (B) Expression profile of ETB protein in CL collected at selected stages of pregnancy and during prepartum luteolysis; $20 \mu \mathrm{g}$ protein was used for each sample. Membranes were re-blotted with $\beta$-ACTIN (45 kDa), which served as an internal loading control. Lower panel in (B) represents densitometric values (standardized optical density; SOD) for ETB expression normalized against $\beta$-ACTIN. All numerical data are presented as the means \pm s.D. Bars with different letters differ at $P<0.001$. $M$, molecular weight marker.

The effect of treatment with the antigestagen aglepristone on luteal ET system expression was investigated in mid-pregnant dogs (40-45 days of gestation). Nontreated mid-pregnant dogs were used as negative controls. Besides the elevated $(P<0.05)$ expression of $E T 1$ (Fig. 4A) and unaffected ( $P>0.05$ ) expression of $E T 2$ (Fig. $4 \mathrm{~B}$ ), the treatment resulted in similar changes to those observed during normal prepartum luteolysis, i.e., $E T 3$ and ETA increased significantly $24 \mathrm{~h}$ after the second treatment $(P<0.05$ and $P<0.01$ respectively), while the expression of ETB remained unchanged $(P>0.05) 24 \mathrm{~h}$ after the second treatment but decreased significantly at $72 \mathrm{~h}(P<0.01)$ and ECE1 remained unaffected $(P>0.05)$ (Fig. 4C, D and E).

Stimulation of canine lutein cells with $20 \mu \mathrm{M}$ PGE2 over a $6 \mathrm{~h}$ time course did not affect the expression of ETA, ET1 and ECE1 ( $P>0.05)$ (Fig. 5A, C and E). Whereas $E T 2$ was significantly decreased $(P<0.01)$ (Fig. 5D), the expression of ETB increased significantly $(P<0.05)$ (Fig. 5B). In contrast, ET3 mRNA expression remained below the detection limit.

\section{Luteal localization of canine ET system expression}

IHC was applied to localize the expression of ET1, ECE1, ETA and ETB at the protein level. Due to the lack of canine-specific anti-ET2 and anti-ET3 antibodies, their expression was assessed by ISH. ET1 was predominantly targeted to the luteal cells without marked changes in signal intensity over time in both situations, i.e., in pregnant and non-pregnant animals (Fig. 6). As for ET2, its mRNA was predominantly found in capillaries (Fig. 7A), while that of ET3 was localized in endothelial cells of small and larger luteal vessels (Fig. 7B). As for ECE1, signals were detectable throughout the luteal
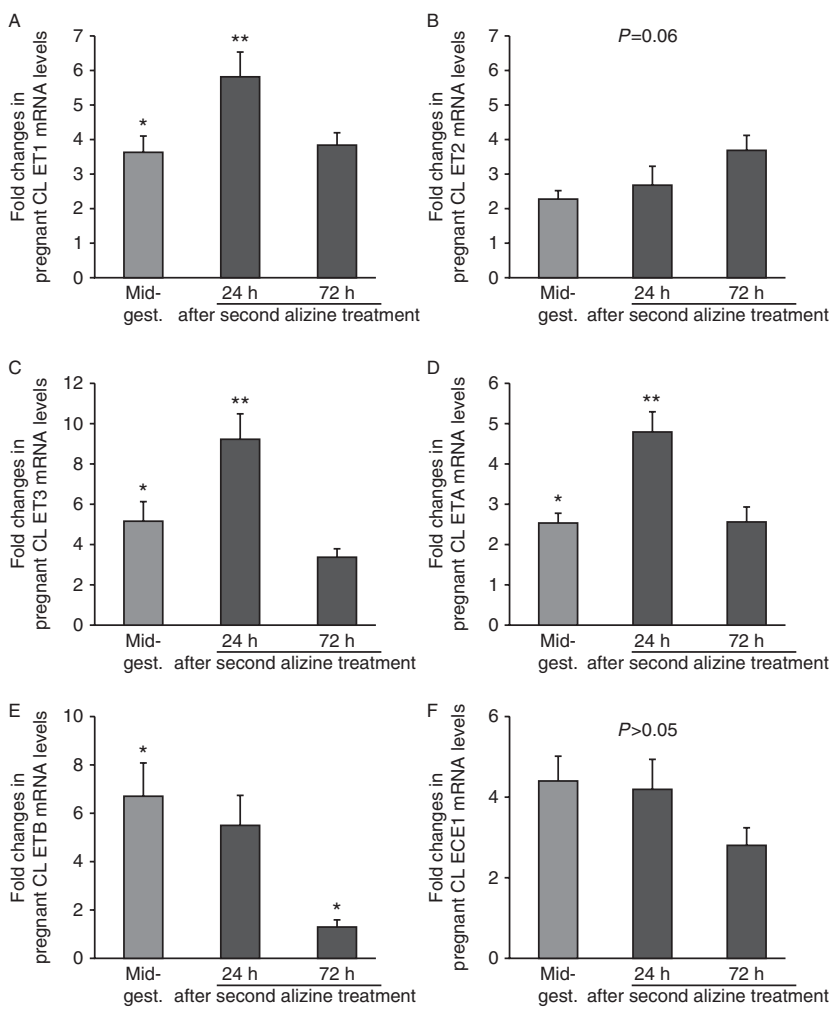

Figure 4 Expression of endothelin system members (ET1, -2, -3, ETA, ETB and ECE1; A-F) as determined by real-time (TaqMan) PCR (mean \pm s.D.) during antigestagen (Aglepristone)-induced luteolysis/ abortion compared with the mid-gestation group used as a non-treated control. Bars with different asterisks differ at $P<0.05$ in $\mathrm{A}$ and $\mathrm{C}$ and $P<0.01$ in $\mathrm{D}$ and $\mathrm{E}$. 

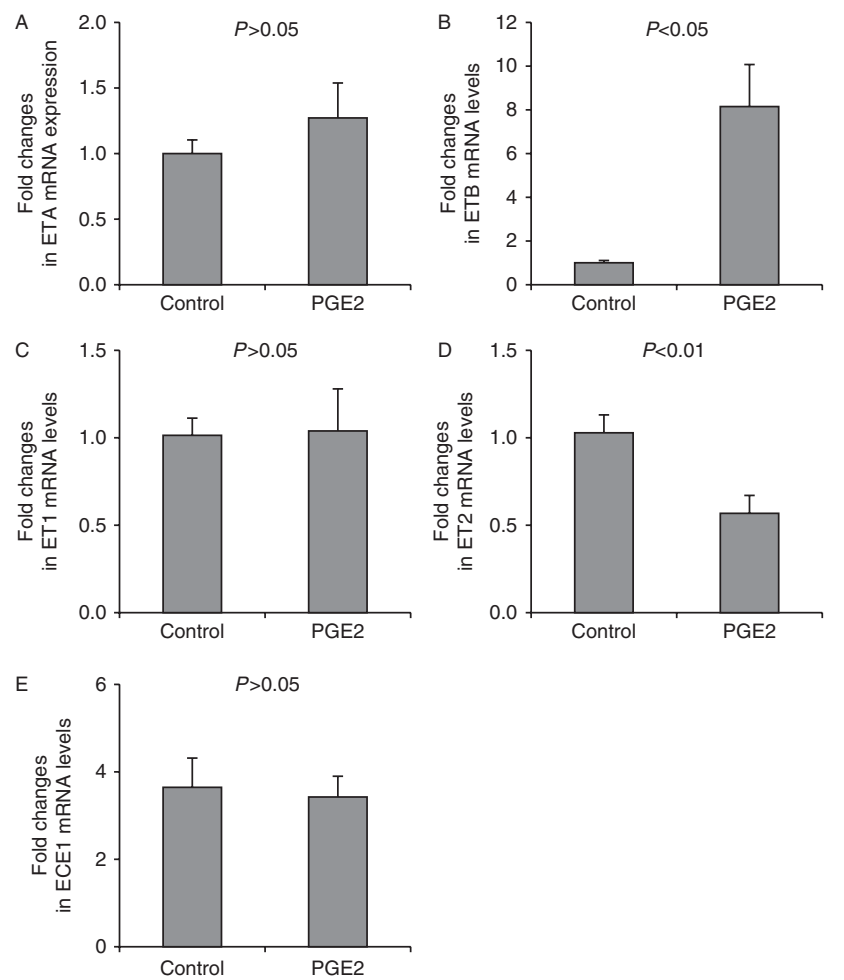

Figure 5 Effect of PGE2 on expression of endothelin system members in canine primary luteal cells collected from non-pregnant dogs during the early $\mathrm{CL}$ phase. Cells were cultured in serum-free DMEM/F12 medium with $20 \mu \mathrm{M}$ PGE2. Non-stimulated cells served as a negative control. (A, B, C, D and E) endothelin receptors - A and -B (ETA and ETB) and endothelins (ET) -1 and -2 mRNA expression as determined by real-time (TaqMan) PCR normalized against cyclophilin A, GAPDH and 18SrRNA.

phase and strong immune signals were localized to the vascular endothelial cells, and weaker expression was detected within the luteal cells (Fig. 8). The luteal signals tended to be stronger in early diestrus of pregnant and non-pregnant cyclic animals. No or only weak signals were observed in $\mathrm{CL}$ for ETA throughout the luteal lifespan but became clearly visible during prepartum luteolysis in pregnant females (Fig. 9B) where its localization was targeted to the endothelial cells of capillaries. In contrast, ETB was clearly detectable and localized in luteal cells, the tunica media of arteries in early CL and some of the interstitial cells (Fig. 10). With the progression of the luteal phase, signal intensity decreased (Fig. 10) and the weakest staining was observed in capillaries and luteal cells during late diestrus and at the prepartum luteolysis in pregnant bitches (Fig. 10).

\section{Discussion}

In this project we evaluated the expression and localization of the members of the ET system in luteal samples from non-pregnant dogs, as well as in $\mathrm{CL}$ collected at selected stages of pregnancy, i.e., preimplantation, post-implantation and mid-gestation, and during normal and antigestagen-induced prepartum luteolysis/abortion.

Whereas the expression of ET1, which was abundantly present in luteal cells, did not change significantly throughout the luteal phase, the early luteal phase of both pregnant and non-pregnant cyclic bitches was characterized by markedly increased levels of vascular $E T 2$. This was associated with concomitantly increased expression of ECE1, which is responsible for enzymatic activation of ETs. A similar expression pattern of ET2 was observed in CL of cows (Klipper et al. 2010), implying a role of this peptide during luteal formation and angiogenesis. The physiological significance of ET2 in ovarian function was recently demonstrated in knockout mice, in which loss of ET2 expression resulted in impaired ovulation and luteal formation (Cacioppo et al. 2014). Importantly, ET2 injection into ovaries of these animals augmented ovulation and increased expression of the cytochrome P450 side chain cleavage
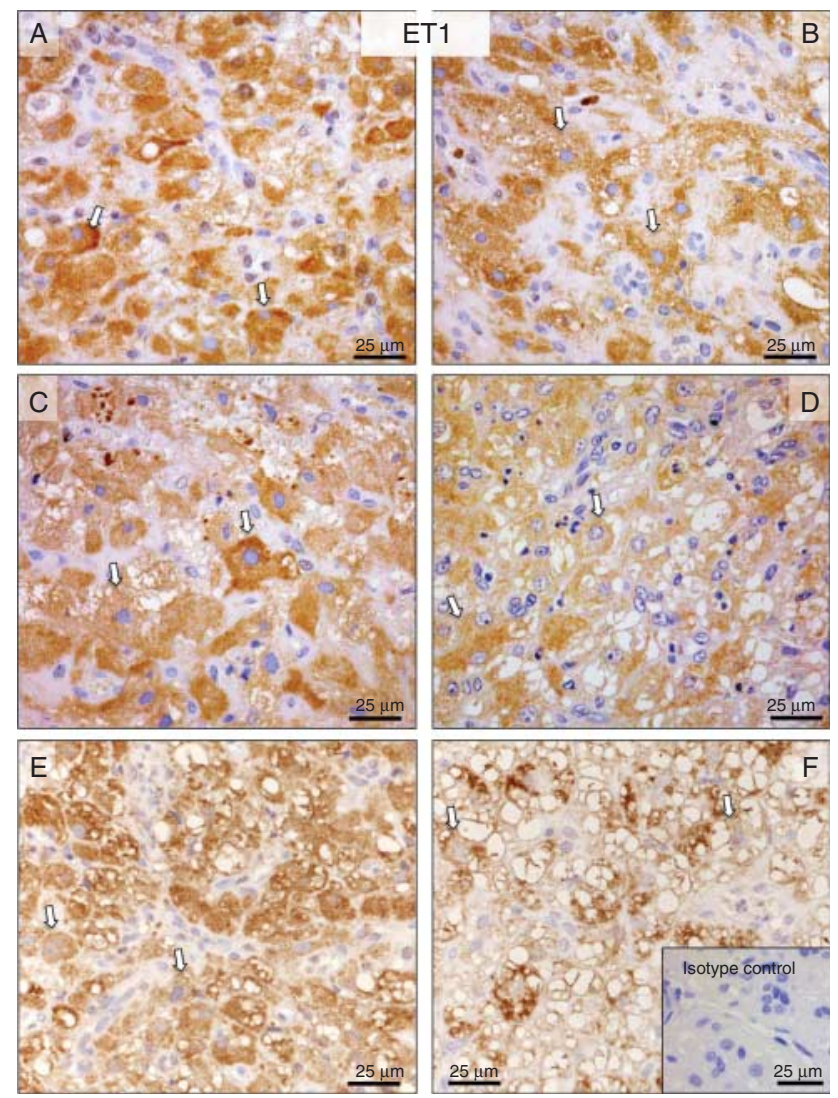

Figure 6 Immunohistochemical localization of ET-1 in the canine CL at selected time points of pregnancy and on days 5 and 65 post-ovulation in non-pregnant animals. (A) Pre-implantation stage, (B) postimplantation, (C) mid-gestation, (D) prepartum luteolysis and on days (E) 15 and (F) 65 post-ovulation in non-pregnant animals. (A, B, C, D, E and F) ET-1 is localized to the luteal cells (open arrows) throughout the luteal phase. There is no background staining in the isotype control (insert to F). 


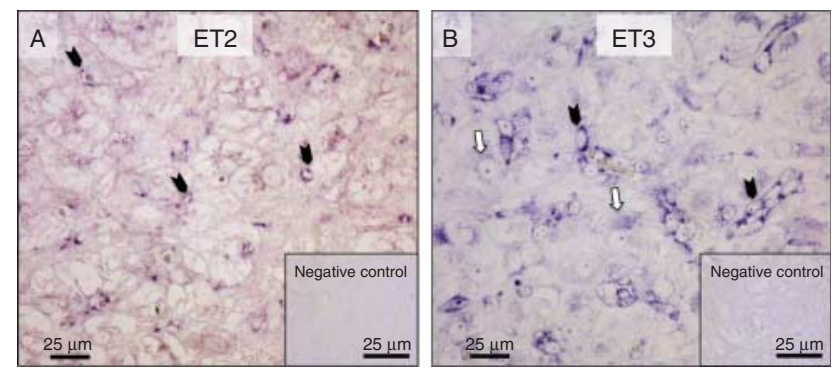

Figure 7 Localization of ET-2 and ET-3 mRNA in the canine CL during prepartum luteolysis by in situ hybridization (ISH). (A) ET-2 mRNA is localized to the capillary endothelial cells (solid arrowheads). (B) ET-3 mRNA is localized in vascular endothelial cells (solid arrowheads) and luteal cells (open arrows). There is no background staining in the negative controls (insert to $\mathrm{A}$ and $\mathrm{B}$ ).

enzyme (P450scc, CYP11A1) (Cacioppo et al. 2014). Similar effects were observed following blockage of the ETB receptor in mice, which also resulted in a decrease and/or delay in follicular rupture (Palanisamy et al. 2006). In the dog, as presented herein, the early luteal development was associated with strongly increased expression of ETB. Interestingly, its localization seemed ubiquitous, being targeted to both lutein cells and blood vessels, suggesting a possible functional interplay between different structural compartments of the $\mathrm{CL}$ with the involvement of ET-dependent pathways. The ETB-mediated proliferative and migratory effects of ETs, e.g., ET1 and ET3, on endothelial cells and smooth muscles of the vascular tunica media, were shown previously (Alberts et al. 1994, Morbidelli et al. 1995). Additionally, by activating the nitric oxide pathway in endothelial cells, ETB is capable of increasing vascular permeability and inducing vasodilation (Tsukahara et al. 1994). Therefore, ETs exhibit both angiogenic and vasoactive properties. The latter, i.e., vasodilatory and proliferative capabilities of ETB, could also apply to early canine $\mathrm{CL}$, which, following ovulation, requires an increased blood supply to facilitate its rapid growth and enhanced functional steroidogenic performance. During this time, PGs are among the most important regulators of canine luteal function (Kowalewski et al. 2013, Kowalewski 2014). Only recently, a functional causality between local PG production and the steroidogenic activity of canine CL was shown (Kowalewski et al. 2015). Thus, blocking luteal COX2 (PTGS2) function with a selective blocker, firocoxib (Previcox, Merial Ltd.), resulted in suppression of luteal PGE2 synthesis and impairment of STAR expression (Kowalewski et al. 2015). Moreover, the expression of prolactin receptor (PRLR) was diminished in bitches treated with this COX2 blocker. On the other hand, in canine luteal cells isolated from early diestrous bitches, PGE2-stimulated PRLR expression, further implying a possible functional relationship between these two regulatory factors (Kowalewski et al. 2015). This seems to be an important observation in view of the role of PRL as the predominant luteotropic factor in dogs during the second half of diestrus (Concannon et al. 1987, Okkens et al. 1990). In line with this, in the present study, stimulation of canine primary lutein cells with PGE2 significantly upregulated their ETB mRNA expression. Therefore, besides being directly involved in the regulation of canine $\mathrm{CL}$ function by stimulating STAR expression and increasing P4 output, PGE2 appears to participate indirectly in the maintenance of canine luteal function by enhancing the expression of PRLR and ETB.

As observed in the present study, the mid and late luteal phases were characterized by decreasing ETB and $E T 2$ expression. This was associated with concomitantly increasing levels of ET3, which together with ET2 was predominantly localized in vascular compartments of the $\mathrm{CL}$. Contrasting with ETB, the potent vasoconstrictor ETA was rather weakly and stably expressed throughout the luteal phase, while its expression increased significantly along with elevated ET2 levels during normal prepartum luteolysis. Interestingly, however, for both

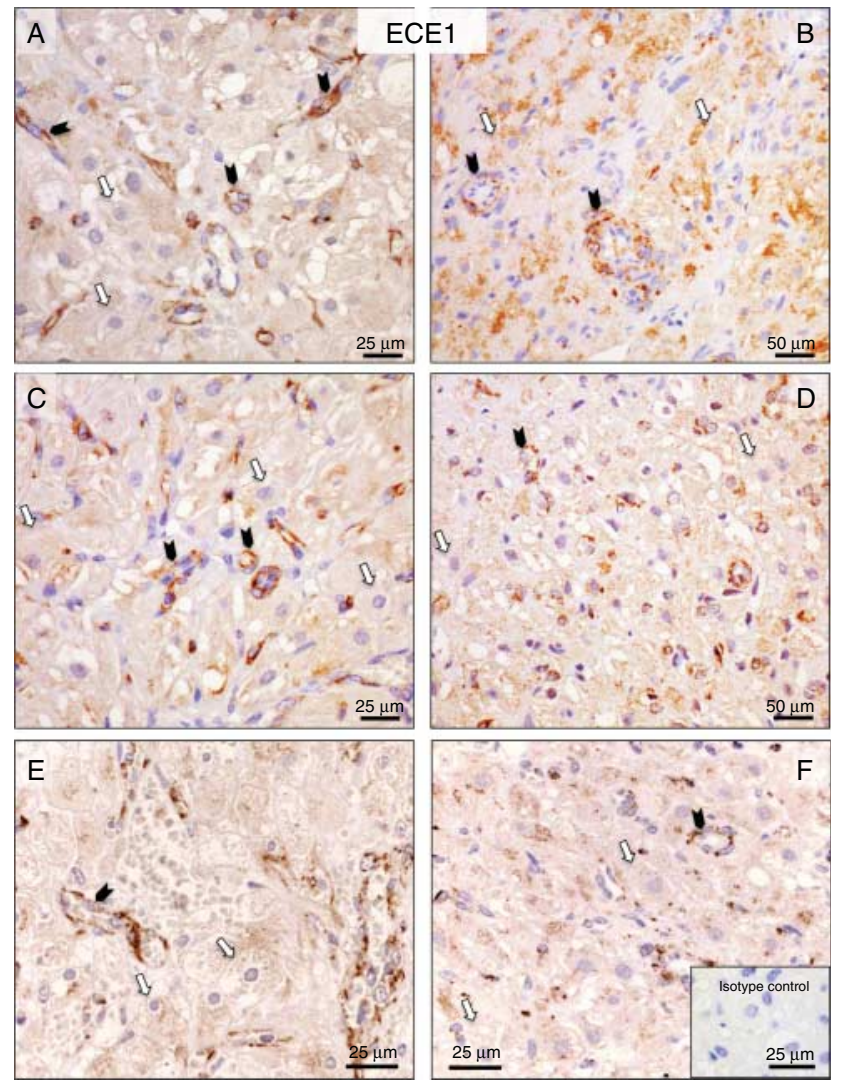

Figure 8 Immunohistochemical localization of endothelin converting enzyme 1 (ECE1) in the CL of pregnant dogs at selected periods of pregnancy and on days 5 and 15 post-ovulation in non-pregnant animals. (A) Pre-implantation stage, (B) post-implantation, (C) mid-gestation (D) prepartum luteolysis and on days (E) 5 and (F) 15 post-ovulation in non-pregnant animals. (A, B, C, D, E and F) ECE-1 expression is localized in luteal cells (open arrows) and vascular endothelial cells (solid arrowheads). There is no background staining in the isotype control (insert to F). 
factors, i.e., ETA and ET2, this was not the case during late luteal regression in non-pregnant animals when their expression remained unchanged.

In the dog, P4 is considered as a luteotropic factor, so that interfering with its function, e.g., by applying an antigestagen, activates the uterine and placental prostaglandin system and induces a luteolytic cascade leading to pre-term parturition/abortion (Kowalewski et al. 2009, 2010a). Accordingly, except for the upregulated ET1 and unaffected ET2 expression, application of an antigestagen on days $40-45$ of gestation, which is a time point distant from physiological parturition, evoked similar changes to those observed during prepartum luteolysis. These changes refer especially to the upregulated expression of ETA, indicating the involvement of $\mathrm{P} 4$ signaling in this process. Interestingly, as shown in this study, while the expression of the vasoactive ET system reveals strong spatio-temporal changes at the end of canine pregnancy, the angiogenic VEGF-system does not change significantly during normal and induced parturition/abortion (Kowalewski 2014). Therefore, cumulatively, it seems plausible that in contrast to nonpregnant dogs, vascular functionality strongly contribute to structural and functional luteolysis in dogs at term, likely due to the PGF2 $\alpha$-induced and ET-mediated vasoconstrictor properties of ETA. The prolonged, slow
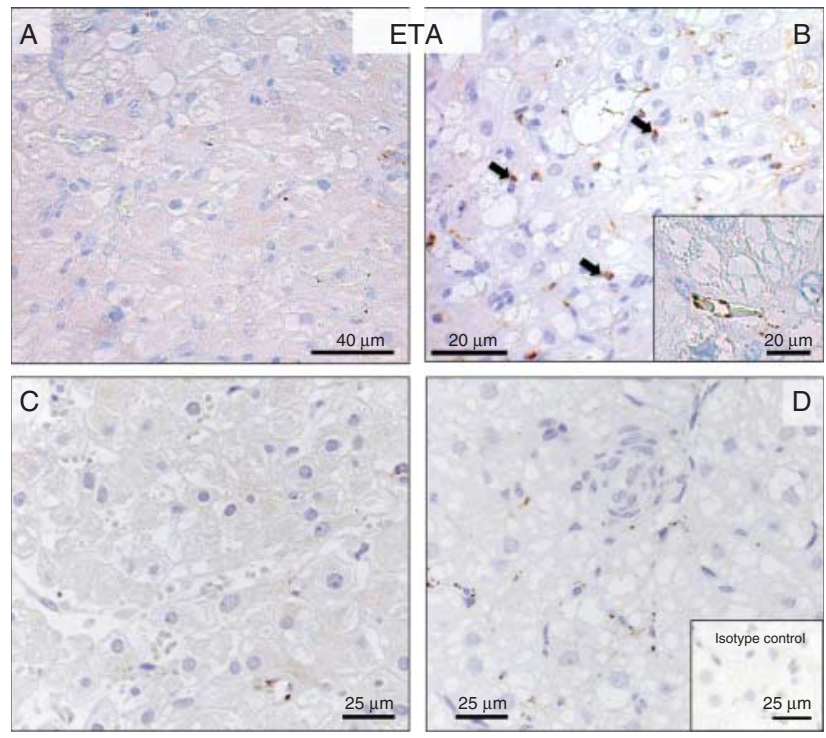

Figure 9 Immunohistochemical localization of endothelin receptor A (ETA) in CL of pregnant dogs at selected time points of pregnancy, and on days 5 and 65 post-ovulation in non-pregnant animals. (A) Preimplantation stage, (B) during prepartum luteolysis and on days (C) 5 and (D) 65 post-ovulation in non-pregnant animals. (A) No or only weak signals were observed during pregnancy in luteal tissue (pre-implantation stage shown). (B) Strong signals were localized in the capillary endothelial cells (solid arrows) during prepartum luteolysis. The capillary endothelial cell expression of ETA is shown at higher magnification in the insert to (B). There was no or only weak staining throughout the non-pregnant diestrus (shown at days 5 and 65 post-ovulation). There is no background staining in the isotype control (insert to D).
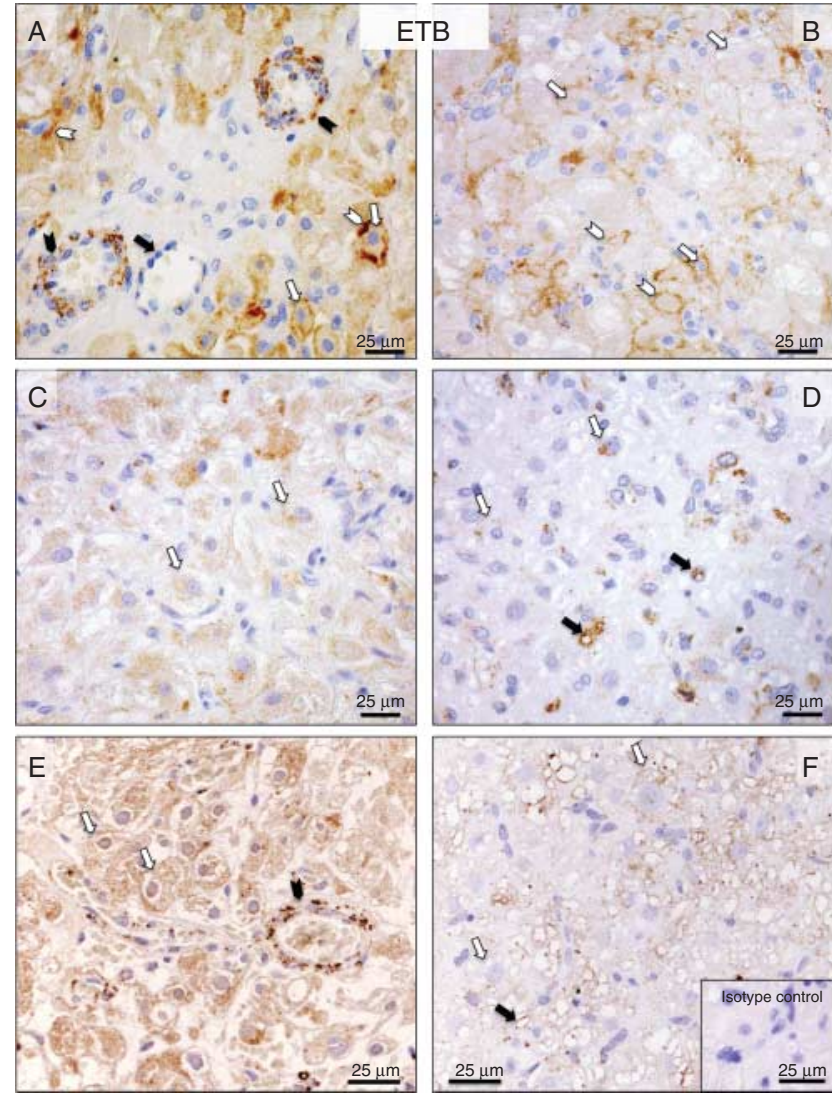

Figure 10 Immunohistochemical localization of endothelin receptor $B$ (ETB) in the CL of pregnant dogs during pregnancy and on days 5 and 65 post-ovulation in non-pregnant bitches. (A) Pre-implantation stage, (B) post-implantation, (C) mid-gestation (D) prepartum luteolysis and on days (E) 5 and (F) 65 post-ovulation in non-pregnant bitches. (A) During pre-implantation, luteal ETB expression is localized to the luteal cells (open arrows), tunica media of arteries (solid arrowheads) and interstitial cells (open arrowheads). (B) At post-implantation and (C) mid-gestation, luteal signals are localized in luteal cells (open arrows) and interstitial cells (open arrowheads in B). (D) During prepartum luteolysis, signals are localized in luteal cells (open arrows) and capillary pericytes (solid arrows). During day (E) 5 post-ovulation in non-pregnant animals, ETB expression is localized to the luteal cells (open arrows) and tunica media of arteries (solid arrowhead). At (F) day 65 post-ovulation in non-pregnant animals, signals are localized in luteal cells (open arrows) and capillary pericytes (solid arrow).

There is no background staining in the isotype control (insert to F).

process of luteal regression observed in non-pregnant animals remains primarily a passive one, at least where vascular activity is concerned.

For conclusion, the role of the ET system during the cessation of luteal function seems to diverge between pregnant and non-pregnant dogs, i.e., being actively regulated, it possibly contributes to the prepartum luteolysis. Its function also differs from the role of the VEGF system, which remains unaffected in both situations (Kowalewski 2014). The role of PGE2 as an important luteotropic factor has been further strengthened by results obtained from our in vitro experiments 
with canine lutein cell cultures, in which PGE2 was found to be a positive regulator of ETB expression.

\section{Declaration of interest}

The authors declare that there is no conflict of interest that could be perceived as prejudicing the impartiality of the research reported.

\section{Funding}

This research was supported by Swiss National Science Foundation (SNSF) research grant number 31003A_160251 to MPK.

\section{Author contribution statement}

A Gram, M P Kowalewski: Idea of the study, experimental design, interpretation of data and writing of the manuscript. M P Kowalewski was responsible for overall supervision of the study. S Latter: involved in the laboratory part of the project, tissue processing. A Boos, B Hoffmann: knowledge transfer, critical discussion of the data, editing of the manuscript. All authors read and approved the final manuscript.

\section{Acknowledgements}

Authors are grateful to Selim Aslan, University of Ankara, Turkey, and his team for the provision of the tissue material, and to Barry Bavister for careful editing of the manuscript. The technical expertise and contribution of Elisabeth Högger and Stefanie Ihle are greatly appreciated.

\section{References}

Alberts GF, Peifley KA, Johns A, Kleha JF \& Winkles JA 1994 Constitutive endothelin-1 overexpression promotes smooth muscle cell proliferation via an external autocrine loop. Journal of Biological Chemistry 269 10112-10118.

Apa R, Miceli F, de Feo D, Mastrandrea ML, Mancuso S, Napolitano M \& Lanzone A 1998 Endothelin-1 inhibits basal and human chorionic gonadotrophin-stimulated progesterone production. Human Reproduction 13 2425-2429. (doi:10.1093/humrep/13.9.2425)

Boiti C, Maranesi M, Dall'aglio C, Pascucci L, Brecchia G, Gobbetti A \& Zerani M 2007 Vasoactive peptides in the luteolytic process activated by PGF $2 \alpha$ in pseudopregnant rabbits at different luteal stages. Biology of Reproduction 77 156-164. (doi:10.1095/biolreprod.106.055889)

Bridges PJ, Jo M, Al Alem L, Na G, Su W, Gong MC, Jeoung M \& Ko C 2010 Production and binding of endothelin-2 (EDN2) in the rat ovary: endothelin receptor subtype A (EDNRA)-mediated contraction. Reproduction, Fertility, and Development 22 780-787. (doi:10.1071/ RD09194)

Cacioppo JA, Oh SW, Kim HY, Cho J, Lin PC, Yanagisawa M \& Ko C 2014 Loss of function of endothelin-2 leads to reduced ovulation and $\mathrm{CL}$ formation. PLoS ONE 9 e96115. (doi:10.1371/journal.pone.0096115)

Choi DH, Kim EK, Kim KH, Lee KA, Kang DW, Kim HY, Bridges P \& Ko C 2011 Expression pattern of endothelin system components and localization of smooth muscle cells in the human pre-ovulatory follicle. Human Reproduction 26 1171-1180. (doi:10.1093/humrep/der066)
Concannon PW, Weinstein P, Whaley S \& Frank D 1987 Suppression of luteal function in dogs by luteinizing hormone antiserum and by bromocriptine. Journal of Reproduction and Fertility 81 175-180. (doi:10.1530/jrf.0.0810175)

Concannon PW, McCann JP \& Temple M 1989 Biology and endocrinology of ovulation, pregnancy and parturition in the dog. Journal of Reproduction and Fertility. Supplement 39 3-25.

Flores JA, Quyyumi S, Leong DA \& Veldhuis JD 1992 Actions of endothelin-1 on swine ovarian (granulosa) cells. Endocrinology 131 1350-1358.

Fraser HM \& Wulff C 2003 Angiogenesis in the corpus luteum. Reproductive Biology and Endocrinology 1 88. (doi:10.1186/14777827-1-88)

Girsh E \& Dekel N 2002 Involvement of endothelin-1 and its receptors in PGF2 $\alpha$-induced luteolysis in the rat. Molecular Reproduction and Development 63 71-78. (doi:10.1002/mrd.10159)

Girsh E, Milvae RA, Wang W \& Meidan R 1996 Effect of endothelin-1 on bovine luteal cell function: role in prostaglandin F2 $\alpha$-induced antisteroidogenic action. Endocrinology 137 1306-1312. (doi:10.1210/endo. 137.4.8625904)

Gram A, Buchler U, Boos A, Hoffmann B \& Kowalewski MP 2013 Biosynthesis and degradation of canine placental prostaglandins: prepartum changes in expression and function of prostaglandin F2 $\alpha$ synthase (PGFS AKR1C3) and 15-prostaglandin dehydrogenase. Biology of Reproduction 89 2. (doi:10.1095/biolreprod.113.109918)

Grazul-Bilska AT, Navanukraw C, Johnson ML, Vonnahme KA, Ford SP, Reynolds LP \& Redmer DA 2007 Vascularity and expression of angiogenic factors in bovine dominant follicles of the first follicular wave. Journal of Animal Science 85 1914-1922. (doi:10.2527/jas. 2007-0044)

Hinckley ST \& Milvae RA 2001 Endothelin-1 mediates prostaglandin F(2 $\alpha)$ induced luteal regression in the ewe. Biology of Reproduction 64 1619-1623. (doi:10.1095/biolreprod64.6.1619)

Hoffmann B, Busges F \& Baumgartner W 2004a Immunohistochemical detection of CD4-, CD8- and MHC II-expressing immune cells and endoglin in the canine corpus luteum at different stages of dioestrus. Reproduction in Domestic Animals 39 391-395. (doi:10.1111/j.14390531.2004.00520.x)

Hoffmann B, Busges F, Engel E, Kowalewski MP \& Papa P $2004 b$ Regulation of corpus luteum-function in the bitch. Reproduction in domestic animals 39 232-240. (doi:10.1111/j.1439-0531.2004.00508.x)

Iwai M, Hasegawa M, Taii S, Sagawa N, Nakao K, Imura H, Nakanishi S \& Mori T 1991 Endothelins inhibit luteinization of cultured porcine granulosa cells. Endocrinology 129 1909-1914. (doi:10.1210/endo129-4-1909)

Kamada S, Blackmore PF, Kubota T, Oehninger S, Asada Y, Gordon K, Hodgen GD \& Aso T 1995 The role of endothelin-1 in regulating human granulosa cell proliferation and steroidogenesis in vitro. Journal of Clinical Endocrinology and Metabolism 80 3708-3714.

Klipper E, Levit A, Mastich Y, Berisha B, Schams D \& Meidan R 2010 Induction of endothelin-2 expression by luteinizing hormone and hypoxia: possible role in bovine corpus luteum formation. Endocrinology 151 1914-1922. (doi:10.1210/en.2009-0767)

Ko C, Gieske MC, Al-Alem L, Hahn Y, Su W, Gong MC, Iglarz M \& Koo Y 2006 Endothelin-2 in ovarian follicle rupture. Endocrinology 147 1770-1779. (doi:10.1210/en.2005-1228)

Kowalewski MP 2014 Luteal regression vs. prepartum luteolysis: regulatory mechanisms governing canine corpus luteum function. Reproductive Biology 14 89-102. (doi:10.1016/j.repbio.2013.11.004)

Kowalewski MP, Mason JI, Howie AF, Morley SD, Schuler G \& Hoffmann B 2006 a Characterization of the canine $3 \beta$-hydroxysteroid dehydrogenase and its expression in the corpus luteum during diestrus. Journal of Steroid Biochemistry and Molecular Biology 101 254-262. (doi:10.1016/ j.jsbmb.2006.06.029)

Kowalewski MP, Schuler G, Taubert A, Engel E \& Hoffmann B $2006 b$ Expression of cyclooxygenase 1 and 2 in the canine corpus luteum during diestrus. Theriogenology 66 1423-1430. (doi:10.1016/j.theriogenology.2006.01.039)

Kowalewski MP, Beceriklisoy HB, Aslan S, Agaoglu AR \& Hoffmann B 2009 Time related changes in luteal prostaglandin synthesis and steroidogenic capacity during pregnancy, normal and antiprogestin induced luteolysis in the bitch. Animal Reproduction Science 116 129-138. (doi:10.1016/ j.anireprosci.2008.12.011) 
Kowalewski MP, Beceriklisoy HB, Pfarrer C, Aslan S, Kindahl H, Kucukaslan I \& Hoffmann B 2010a Canine placenta: a source of prepartal prostaglandins during normal and antiprogestin-induced parturition. Reproduction 139 655-664. (doi:10.1530/REP-09-0140)

Kowalewski MP, Dyson MT, Boos A \& Stocco DM 2010b Vasoactive intestinal peptide (VIP)-mediated expression and function of steroidogenic acute regulatory protein (StAR) in granulosa cells. Molecular and Cellular Endocrinology 328 93-103. (doi:10.1016/j.mce.2010.07.018)

Kowalewski MP, Meyer A, Hoffmann B, Aslan S \& Boos A 2011 Expression and functional implications of peroxisome proliferator-activated receptor $\gamma(\mathrm{PPAR} \gamma)$ in canine reproductive tissues during normal pregnancy and parturition and at antiprogestin induced abortion. Theriogenology 75 877-886. (doi:10.1016/j.theriogenology.2010.10.030)

Kowalewski MP, Fox B, Gram A, Boos A \& Reichler I 2013 Prostaglandin E2 functions as a luteotrophic factor in the dog. Reproduction 145 213-226. (doi:10.1530/REP-12-0419)

Kowalewski MP, Ihle S, Siemieniuch MJ, Gram A, Boos A, Zdunczyk S, Fingerhut J, Hoffmann B, Schuler G, Jurczak A et al. 2015 Formation of the early canine $\mathrm{CL}$ and the role of prostaglandin E2 (PGE2) in regulation of its function: an in vivo approach. Theriogenology 83 1038-1047. (doi:10.1016/j.theriogenology.2014.12.006)

Mariani TC, do Prado C, Silva LG, Paarmann FA, Lima MC, Carvalho I, Campos DB, Artoni LP, Hernandez-Blazquez FJ \& Papa PC 2006 Immunohistochemical localization of VEGF and its receptors in the corpus luteum of the bitch during diestrus and anestrus. Theriogenology 66 1715-1720. (doi:10.1016/j.theriogenology.2006.02.030)

Martelli A, Palmerini MG, Russo V, Rinaldi C, Bernabo N, Di Giacinto O, Berardinelli P, Nottola SA, Macchiarelli G \& Barboni B 2009 Blood vessel remodeling in pig ovarian follicles during the periovulatory period: an immunohistochemistry and SEM-corrosion casting study. Reproductive Biology and Endocrinology 7 72. (doi:10.1186/14777827-7-72)

Milvae RA 2000 Inter-relationships between endothelin and prostaglandin F2 $\alpha$ in corpus luteum function. Reviews of Reproduction 5 1-5. (doi:10.1530/ror.0.0050001)

Morbidelli L, Orlando C, Maggi CA, Ledda F \& Ziche M 1995 Proliferation and migration of endothelial cells is promoted by endothelins via activation of ETB receptors. American Journal of Physiology 269 H686-H695.

Na G, Bridges PJ, Koo Y \& Ko C 2008 Role of hypoxia in the regulation of periovulatory EDN2 expression in the mouse. Canadian Journal of Physiology and Pharmacology 86 310-319. (doi:10.1139/Y08-025)

Nussdorfer GG, Rossi GP, Malendowicz LK \& Mazzocchi G 1999 Autocrine-paracrine endothelin system in the physiology and pathology of steroid-secreting tissues. Pharmacological Reviews 51 403-438.

Ohtani M, Kobayashi S, Miyamoto A, Hayashi K \& Fukui Y 1998 Real-time relationships between intraluteal and plasma concentrations of endothelin, oxytocin, and progesterone during prostaglandin F2 $\alpha$ induced luteolysis in the cow. Biology of Reproduction 58 103-108. (doi:10.1095/biolreprod58.1.103)

Okkens AC, Bevers MM, Dieleman SJ \& Willemse AH 1990 Evidence for prolactin as the main luteotrophic factor in the cyclic dog. Veterinary Quarterly 12 193-201. (doi:10.1080/01652176.1990.9694266)

Palanisamy GS, Cheon YP, Kim J, Kannan A, Li Q, Sato M, Mantena SR, Sitruk-Ware RL, Bagchi MK \& Bagchi IC 2006 A novel pathway involving progesterone receptor, endothelin-2, and endothelin receptor B controls ovulation in mice. Molecular Endocrinology 20 2784-2795. (doi:10.1210/me.2006-0093)

Papa Pde C, Sousa LM, Silva Rdos S, de Fatima LA, da Fonseca VU, do Amaral VC, Hoffmann B, Alves-Wagner AB, Machado UF \& Kowalewski MP 2013 Glucose transporter 1 expression accompanies hypoxia sensing in the cyclic canine corpus luteum. Reproduction $\mathbf{1 4 7}$ 81-89. (doi:10.1530/REP-13-0398)

Reynolds LP, Grazul-Bilska AT \& Redmer DA 2000 Angiogenesis in the corpus luteum. Endocrine 12 1-9. (doi:10.1385/ENDO:12:1:1)

Sprekeler N, Kowalewski MP \& Boos A 2012 TRPV6 and CalbindinD9k-expression and localization in the bovine uterus and placenta during pregnancy. Reproductive Biology and Endocrinology 1066. (doi:10.1186/1477-7827-10-66)

Suzuki T, Sasano H, Takaya R, Fukaya T, Yajima A \& Nagura H 1998 Cyclic changes of vasculature and vascular phenotypes in normal human ovaries. Human Reproduction 13 953-959. (doi:10.1093/ humrep/13.4.953)

Tedeschi C, Lohman C, Hazum E, Ittoop O, Ben-Shlomo I, Resnick CE, Payne DW \& Adashi EY 1994 Rat ovarian granulosa cell as a site of endothelin reception and action: attenuation of gonadotropinstimulated steroidogenesis via perturbation of the A-kinase signaling pathway. Biology of Reproduction 51 1058-1065. (doi:10.1095/ biolreprod51.5.1058)

Tsukahara H, Ende H, Magazine HI, Bahou WF \& Goligorsky MS 1994 Molecular and functional characterization of the non-isopeptideselective ETB receptor in endothelial cells. Receptor coupling to nitric oxide synthase. Journal of Biological Chemistry 269 21778-21785.

Watanabe S, Shirasuna K, Matsui M, Yamamoto D, Berisha B, Schams D \& Miyamoto A 2006 Effect of intraluteal injection of endothelin type A receptor antagonist on PGF2 $\alpha$-induced luteolysis in the cow. Journal of Reproduction and Development 52 551-559. (doi:10.1262/ jrd.18018)

Wright MF, Sayre B, Keith Inskeep EK \& Flores JA 2001 Prostaglandin F $(2 \alpha)$ regulation of the bovine corpus luteum endothelin system during the early and midluteal phase. Biology of Reproduction 65 1710-1717. (doi:10.1095/biolreprod65.6.1710)

Yanagisawa M \& Masaki T 1989 Endothelin, a novel endothelium-derived peptide. Pharmacological activities, regulation and possible roles in cardiovascular control. Biochemical Pharmacology 38 1877-1883. (doi:10.1016/0006-2952(89)90484-X)

Yanagisawa M, Kurihara H, Kimura S, Tomobe $Y$, Kobayashi M, Mitsui Y, Yazaki Y, Goto K \& Masaki T 1988 A novel potent vasoconstrictor peptide produced by vascular endothelial cells. Nature 332 411-415. (doi:10.1038/332411a0)

Zalman Y, Klipper E, Farberov S, Mondal M, Wee G, Folger JK, Smith GW \& Meidan R 2012 Regulation of angiogenesis-related prostaglandin $\mathrm{f} 2 \alpha$-induced genes in the bovine corpus luteum. Biology of Reproduction 86 92. (doi:10.1095/biolreprod.111.095067)

Received 2 June 2015

First decision 6 July 2015

Revised manuscript received 27 July 2015

Accepted 3 August 2015 